\title{
Tax Policy Changes and Ex-Dividend Behavior: The Case of Sweden*
}

\author{
Sven-Olov Daunfeldt \\ Umeå University
}

February 20, 2002

\begin{abstract}
The purpose of the paper is to study how changes in the Swedish tax system have influenced stock prices and trading volumes around the ex-dividend day. The hypothesis that the ex-dividend price ratio is unaffected by the relatively large tax policy changes in Sweden cannot be rejected, and the tax clientele hypothesis is not supported by the data. On the other hand, the results are not all together supportive of the short-term trading hypothesis. For instance, the results do not confirm the predicted and previously documented positive relationship between abnormal volumes and dividend yields.
\end{abstract}

Key words: ex-dividend; capital gains; taxation; event study.

JEL classification: G12; G14; G35; H24.

\section{Introduction}

The purpose of this paper is to study how marginal taxes on dividends and capital gains influence stock prices and trading volumes in the period around the ex-dividend day. In an economy with perfect capital markets, Miller and Modigliani (1961) showed that shareholders are indifferent between dividends and future earnings. This implies that the stock price should decline on the ex-dividend day and that the decline should equal the size

\footnotetext{
${ }^{*}$ I would like to thank Thomas Aronsson, Mikael Bask, Jörgen Hellström, Xavier de Luna, John Karl Scholz and Magnus Wikström for valuable comments on a previous version of this article. I would also like to thank Henrik Nilsson and Rickard Olsson for providing data. Financial support from the Swedish Institute is gratefully awknowleged.
} 
of the dividend per share. If this is not the case, investors can exploit the difference to make a profit from arbitrage. However, early empirical studies (e.g., Campbell and Beranek, 1953; Durand and May, 1960) indicated that the ratio of the price change to the dividend per share (the so called ex-dividend price ratio) was less than one and positively correlated with the dividend yield.

Elton and Gruber (1970) showed that the ex-dividend price ratio can be used to infer the differential taxation of dividends and capital gains for the marginal stockholder and that the ex-dividend price ratio, in an economy where capital gains are taxed more favorably than dividends, should be lower for stocks attracting shareholders in high income tax brackets. Accordingly, they interpreted the positive correlation between the ex-dividend price ratio and the dividend yields as a result of tax-induced clienteles, i.e., investors with high marginal tax rates hold low dividend yield stocks and those in lower income tax brackets hold high dividend yield stocks.

On the other hand, Kalay $(1982,1984)$ and Miller and Scholes (1982) argued that marginal tax rates cannot be derived from the ex-dividend price ratio because professional traders (e.g., institutional investors) and private investors face different tax rules. Given that private investors are price setters, this means that institutional investors can exploit the ex-dividend price change to make arbitrage profits. Following previous literature, this theory is henceforth defined as the short-term trading hypothesis, while the Elton and Gruber (1970) theory is defined as the tax clientele hypothesis. The short-term trading hypothesis is supported by empirical work (e.g., Lakonishok and Vermaelen, 1986; Karpoff and Walkling, 1988; Michaely and Vila, 1995; Athanassakos, 1996) indicating abnormally high trading volumes around the ex-dividend day.

In this study, daily data from the Swedish stock market during the period 1988-1995 are used to analyze how changes in the Swedish tax system have influenced stock prices and trading volumes in the period around the exdividend day. Examples of previous studies of regime shifts in tax policy and ex-dividend behavior are Booth and Johnston (1984), Poterba and Summers (1984), Barclay (1987), Michaely (1991), Robin (1991), Athanassakos and Fowler (1993), Skinner (1993), de Ridder and Södersten (1995) and Wu and Hsu (1996). The results from these studies are, however, inconclusive. Some of the studies (e.g., Poterba and Summers, 1984; Barclay, 1987; Robin, 1991), present results that indicate that taxes influence ex-dividend behavior while other studies (e.g., Skinner, 1993; de Ridder and Södersten, 1995) 
conclude the opposite. ${ }^{1}$ In this paper, we can identify three distinct tax regimes in Sweden during period under study, i.e., capital gains have, in relation to dividends, been taxed at a higher, equal and lower marginal tax rate. In relation to previous studies, this provides us with greater variation in the relative taxation of dividends and capital gains.

The estimation period coincides, moreover, with the implementation of the major Swedish tax reform in 1991. Note that the tax clientele hypothesis implicitly assumes that dividends and capital gains are taxed as earned income. In the case when they are taxed at a uniform rate irrespective of the level of earned income, as after the 1991 Swedish tax reform, variation in the ex-dividend price ratio cannot be explained by tax induced clienteles. Hence, the Swedish tax reform provides a unique opportunity to examine the tax clientele hypothesis using aggregate data from the stock market. The flat tax rate of dividends and capital gains also implies that direct measures of the relative tax treatment of dividends and capital gains can be included in the empirical analysis. Tax policy changes can thereby be separated from other developments over time, e.g., technological changes and changes in transaction costs.

Another advantage is that dividends are paid once a year in Sweden (usually in May), whereas in many other countries (e.g., USA) dividends are paid quarterly. Since transaction costs become more important when dividends are relatively small, and act like a barrier against short term trading, it is more likely that changes in the tax environment influence the behavior of the short-term traders. On the other hand, the cum-dividend day in Sweden coincides with the annual general meeting of shareholders. Abnormal volumes can, therefore, also be observed due to released information and/or increased publicity for the firm.

The results from the empirical study cannot reject the hypothesis that the ex-dividend price ratio is unaffected by the relatively large tax changes in Sweden during the 1990s. In addition, no support for the tax clientele hypothesis is found. On the other hand, despite weak indications that trading volumes are most pronounced for the periods when capital gains and dividends are taxed differently, the results are not all together supportive of the short term trading hypothesis. In contrast to the predictions of the short term trading model and the results from previous empirical studies,

\footnotetext{
${ }^{1} \mathrm{~A}$ number of these studies only consider price data. This is a limitation because we may observe an ex-dividend price ratio less than one, despite tax induced clienteles and short-term trading. Ex-dividend trading is, for instance, associated with transaction costs (Kalay, 1982), a non negligable price risk (Heath and Jarrow, 1988), and stock prices are constrained to discrete intervalls while dividends are continous (Bali and Hite, 1998).
} 
no statistically significant positive relation between abnormal volumes and dividend yields is observed in the data. In 1994, when dividends were taxed more favorably than capital gains, the results indicate that high trading volumes were most pronounced for low dividend yield stocks.

The paper is organized as follows. Section 2 presents the theoretical framework. Section 3 contains a description of the tax policy changes in Sweden during the 1990s. The data and the empirical methods are introduced in section 4. In Section 5, the empirical results are presented and commented. Finally, section 6 concludes the article.

\section{Theory}

Given that the rules of taxation are equivalent for all stockholders, a riskneutral investor is indifferent between selling a stock on the cum-dividend day or on the ex-dividend day only if the expected price change is equal to the dividend received. Formally, this can be written as

$$
P_{c}-\tau_{g}\left(P_{c}-P_{o}\right)-c=E\left(P_{x}\right)-\tau_{g}\left(E\left(P_{x}\right)-P_{o}\right)+\left(1-\tau_{d}\right) D-c,
$$

where $P_{o}, P_{c}$ and $E\left(P_{x}\right)$ are the purchasing price of the stock, the price of the stock on the cum-dividend day, and the expected price of the stock on the ex-dividend day. $D$ denotes the dividend per share, $c$ is a fix transaction cost, and the tax on capital gains and dividends is given by $\tau_{g}$ and $\tau_{d}$, respectively.

Equation (1) can be rewritten and simplified in the following way

$$
\frac{P_{c}-E\left(P_{x}\right)}{D}=\frac{1-\tau_{d}}{1-\tau_{g}}
$$

where $\frac{P_{c}-E\left(P_{x}\right)}{D}$ is the so-called ex-dividend price ratio. If $\tau_{d}=\tau_{g}$, then the right-hand side of equation (2) is equal to one and the change in the stock price is equal to the dividend received. On the other hand, if $\tau_{d}>\tau_{g}$, then the ex-dividend price ratio should be less than one; while it should be greater than one if $\tau_{d}<\tau_{g}$. Using US data, Elton and Gruber (1970) found that the ex-dividend price ratio was less than one, and that it was closer to one for low dividend yield stocks than for high dividend yield stocks. ${ }^{2}$ In accordance with their theory, this result was interpreted as a tax clientele

\footnotetext{
${ }^{2}$ Dividend yields are measured as $D / P_{c}$.
} 
effect, i.e., investors with high marginal taxes hold low dividend yield stocks while those in lower income tax brackets hold high dividend yield stocks. ${ }^{3}$

However, Kalay $(1982,1984)$ argued that the ex-dividend price ratio will also be influenced by the trading strategies of professional institutional traders. The reason is that institutional investors face different marginal tax rates than private investors, and can, therefore, exploit the ex-dividend day price change to make arbitrage profits. To show this formally, assume that private investors face a lower marginal tax rate on capital gains than on dividends (as in most countries), i.e., $\tau_{d}>\tau_{g}$; while $\tau_{d}=\tau_{g}=\tau$ is valid for institutional investors. ${ }^{4}$ When the expected ex-dividend price ratio is determined by private investors differential taxation of dividends and capital gains, as suggested by Elton and Gruber (1970), equation (2) implies that the dividend per share is larger than the price change between the cum and the ex-dividend day. Kalay (1982) shows that institutional investors, in this case, will buy shares on the cum-dividend day and sell them on the ex-dividend day, as long as the after tax dividend exceeds the expected after tax capital loss (associated with having the share when it goes ex-dividend) and the transaction costs associated with trading in the period around the ex-dividend day. When it is assumed that capital losses are fully deductible this can formally be written as

$$
(1-\tau) D>(1-\tau)\left(P_{c}-E\left(P_{x}\right)\right)+2 c(1-\tau) .
$$

Thus, given that the expected ex-dividend price ratio is determined by private investors preferential tax treatment of capital gains, institutional investors will intervene at the stock market as long as

$$
\frac{P_{c}-E\left(P_{x}\right)}{D}<1-\frac{2 c}{D}
$$

\footnotetext{
${ }^{3}$ To illustrate this result, assume that dividends are fully taxed as earned income and that capital gains only are taxable at 40 percent. According to equation (2), the exdividend price ratio for an investor with a marginal tax rate of 60 percent is then given by $(1-0.6) /(1-0.24)=0.53$; while the ex-dividend price ratio for a stockholder in a lower income tax bracket (e.g., $\tau_{d}=40$ percent) is given by $(1-0.4) /(1-0.16)=0.71$. Note that variation in the ex-dividend price ratio cannot be explained by the tax-induced clientele effect when dividends and capital gains are taxed at a flat tax rate irrespective of the level of earned income.

${ }^{4}$ Examples of institutional investors are market makers and pension funds. In a tax system were dividends and capital gains are taxed as earned income (e.g., USA), institutional investors generally face the same tax rates on both sources of income (see e.g., Kalay, 1982; Boyd and Jagannathan, 1994). Thus, in a small open economy like Sweden, domestic stock prices can be governed by the arbitrage behavior of foreign institutional investors.
} 
On the other hand, when dividends are taxed at a lower rate than capital gains for private investors (i.e., $\tau_{d}<\tau_{g}$ ), institutional investors will sell shares on the cum-dividend day and buy them on the ex-dividend day as long as the expected after tax capital loss exceeds the dividend per share and the transaction costs associated with a round trip, i.e.,

$$
(1-\tau)\left(P_{c}-E\left(P_{x}\right)\right)>(1-\tau) D+2 c(1-\tau) .
$$

Hence, when the ex-dividend price ratio is determined by private investors preferential tax treatment of dividends, an institutional investor will intervene in the stock market to make arbitrage profit as long as

$$
\frac{P_{c}-E\left(P_{x}\right)}{D}>1+\frac{2 c}{D} .
$$

This means that institutional investors will exploit the possibilities for arbitrage until either equation (3) or (4) no longer holds. Stock prices will, therefore, be influenced by the trading strategy of institutional investors. Accordingly, Kalay $(1982,1984)$ argues that marginal tax rates cannot be infered from the ex-dividend price ratio as suggested by Elton and Gruber (1970).

The fundamental assumption of the short-term trading hypothesis is that different types of investors face different taxation rules. When $\tau_{d}=\tau_{g}=\tau$ is valid for all investors, no arbitrage opportunities exist for institutional investors. Hence, the profit opportunities for institutional investors in the period around the ex-dividend day are directly related to the degree of tax heterogenity. We should, therefore, observe higher trading volumes when the relative difference in the taxation of dividends and capital gains is considerable among private investors. ${ }^{5}$

From equations (3) and (4), it follows that the absence of profit opportunities for institutional investors is inversely proportional to the dividend yield. ${ }^{6}$ As a consequence, institutional investors should concentrate their ex-dividend trading on high dividend yield stocks. Thus, trading volumes should be more pronounced for stocks with higher dividend yields.

Moreover, equations (3) and (4) imply that the ex-dividend price ratio is constrained to unity if transaction costs are zero. Higher transaction costs should, therefore, act as a barrier against short-term trading in the period

\footnotetext{
${ }^{5}$ For a formal proof of this statement, see Michaely and Vila (1995).

${ }^{6}$ For example, assume that the dividend yield is 2 percent; while the expected transaction cost of ex-dividend day trading is 0.2 percent. Given that $\tau_{d}>\tau_{g}$, an institutional investor will intervene at the stock market as long as $\left(P_{c}-E\left(P_{x}\right) / D\right)<0.9$. On the other hand, if the dividend yield is 1 percent the bound is $\left(P_{c}-E\left(P_{x}\right) / D\right)<0.8$.
} 
around the ex-dividend day and, thereby, reduce the volume of trading and the ex-dividend price ratio. Several empirical studies (e.g., Karpoff and Walking, 1988; Michaely and Murgia, 1995; Michaely and Vila, 1996) have also confirmed this result.

Note finally that equations (3) and (4) only hold with regard to expectations because the ex-dividend day price change is not known with certainty. Ex-dividend day trading is, therefore, subject to a non negligible price risk. Even if we use the opening and not the closing price of the stock when it goes ex-dividend, investors are still exposed to an overnight trading risk because firm specific and macroeconomic information may be announced before the opening of the stock market. This implies that the profit opportunities for institutional investors are negatively related to the individual price risk of the stock (see Heath and Jarrow, 1988)

\section{Swedish tax regimes 1988-1995}

In Sweden dividends and capital gains have, as in many other countries, been taxed at different rates. More specifically, the marginal tax rate on capital gains has traditionally been lower than the marginal tax rate on dividends. However, during the period studied (1988-1995), capital gains have, in relation to dividends, been taxed at a lower, equal and higher marginal tax rate. Table 1 provides an overview of these three Swedish tax regimes.

\section{Table 1 About Here}

During the period 1988-1990, both dividends and capital gains were taxed as earned income. Long term capital gains were, however, taxed at a lower rate than dividends. The reason for this was that capital gains realized after two years were only taxable at 40 percent. This is illustrated in Table 1, where the marginal tax rate on earned income for the individual is assumed to be 54 percent. The relation between the marginal tax rate on dividends and capital gains changed in 1991, when a major tax reform was implemented in Sweden. According to the 1991 tax reform, capital gains and dividends were to be taxed (independently of earned income) at a uniform rate of 30 percent. As can be seen from Table 1, already in 1992 the capital gains tax rate was reduced from 30 to 25 percent. Furthermore, in 1994 , the tax on dividends was removed and the tax on capital gains was substantially reduced. However, these taxes were reintroduced at a uniform rate of 30 percent in 1995. Hence, during the period 1988-1995, we can observe three different relationships between the tax on capital gains and 
dividends, as well as the implementation of a major tax reform. ${ }^{7}$

\section{Data and Empirical Method}

\subsection{Data}

Data from the Stockholm stock market during the period 1988-1995 are used to study whether the observed tax policy changes influence ex-dividend behavior. The data contain information on daily trading volumes and opening and closing prices. Information on ex-dividend dates and the size of the dividends is obtained from Bonniers Findata and Delphi Economics, respectively. When data are missing, this information is instead gathered from the daily Swedish newspaper Dagens Nyheter. The sample is restricted to firms that pay out dividends and shares that have been traded both on the cum and the ex-dividend day. Moreover, to be included in the sample, at least thirty daily returns in the period prior to the event window must be observed. Five extreme outliers are also excluded from the sample. ${ }^{8}$ The total number of ex-dividend dates considered is 371 and the number of firms varies from 36 for 1989 to 75 in 1995. Descriptive statistics for the sample and the tax information are presented in Table 2.

\section{Table 2 ABOUT HERE}

The sample statistics show that the ex-dividend price ratio, on average, is less than one for all of the tax regimes studied. This implies that the average decline in the stock price on the ex-dividend day is less than the dividend per share, regardless of the tax regime considered. Note that the Elton and Gruber (1970) model predicts (see equation (2)) a larger exprice decline than the dividend per share in 1994 because capital gains were tax penalized compared with dividends. According to Table 2, the average dividend yield is 2.73 percent. This means that the dividend yield in this study, on average, is larger than the dividend yields observed in previous ex-dividend studies ${ }^{9}$.

\footnotetext{
${ }^{7}$ In their comprehensive survey, Agell et al. (1998, p. 1) classify the 1991 Swedish tax reform as the "most far-reaching tax reform in any western industrialized country" in recent decades.

${ }^{8}$ The observations that are not included in the final sample have a standardized abnormal volume that exceeds five. For a formal describtion of standardized abnormal volumes $(S A V)$, see subsection 4.3 in this paper.

${ }^{9}$ For instance, the average dividend yield is approximately 1 percent in Lakonishok and Vermaelen (1986). This is, however, not surprising since dividends are paid quarterly in the US and once a year in Sweden.
} 


\subsection{The ex-dividend day price change}

First, to account for the risk associated with dividend related trading, a beta value $\left(b_{i t}\right)$ is estimated using daily data from the year preceding the event window

$$
R_{i s}=a_{i}+b_{i t} R_{m s}+e_{i s},
$$

where $R_{i s}$ is the individual return on stock $i(i=1, \ldots, n)$ on day $s, a_{i}$ is a constant, $R_{m s}$ is the market return on day $s$ (approximated by Affärsvärlden's value weighted general index $), t$ denotes the year $(t=1988, \ldots, 1995)$ and $e_{i s}$ is the error term.

According to the Elton and Gruber (1970) model (see equation (2)) we expect that the ex-dividend price ratio is driven by the differential tax treatment of dividends and capital gains. However, previous empirical studies (e.g., Skinner, 1993; Michaely and Vila, 1995) have shown that the exdividend price ratio also is negatively correlated with the beta value and positively correlated with the dividend yield. This implies that failing to control for these variables may lead to a conclusion that tax changes influence the ex-dividend price ratio, when this result may instead be associated with the trading risk or the dividend yield. Moreover, as previously noted Lakonishok and Vermaelen (1986), equation (3) and (4) implies that the documented positive relation between the ex-dividend price ratio and the dividend yield can be a consequence of the tax clientele hypothesis and/or the short-term trading hypothesis. Using price data, previous studies have not been able to distinguish between these competing hypothesis because only tax regimes where dividends and capital gains are taxed as earned income have been considered. When dividends and capital gains are taxed at a uniform rate regardless of the level of earned income, as in Sweden after the 1991 tax reform, a positive correlation between the ex-dividend price ratio and the dividend yield can no longer be due to the tax clientele effect. The dividend yield effect is therefore studied separately for the period preceding and following the 1991 tax reform.

To study how regime shifts in the differential taxation of dividends and capital gains affect the ex-dividend price ratio, the model to be estimated for the full sample period (1988-1995) is given by

$$
\begin{aligned}
\frac{P_{c i t}-P_{x i t}}{D_{i t}}= & \alpha+\beta b_{i t}+\theta\left(\frac{D_{i t}}{P_{c i t}} \times I_{88-90}\right)+\gamma\left(\frac{D_{i t}}{P_{c i t}} \times I_{91-95}\right) \\
& +\sum_{j=1}^{3} \delta_{j} T_{j}+\varepsilon_{i t},
\end{aligned}
$$


where the dependent variable is the ex-dividend price ratio in year $t$ for stock $i$, the risk of trading is measured as the beta value for stock $i\left(b_{i t}\right)$, $D_{i t}$ denotes as before the dividend per share, $\alpha$ is a constant, $\varepsilon_{i t}$ is the disturbance term, and $I_{88-90}$ and $I_{91-95}$ are indicator variables representing the periods when dividends and capital gains were taxed as earned income (1988-1990) and as independent of earned income (1991-1995), respectively. The changes in the relative taxation of dividends and capital gains during the period studied are characterized by the dummy variable $T_{j}$; describing the dividend falling within tax regime $j(j=1,2,3)$. These tax regimes are defined below.

The closing price on the cum dividend day and the opening price on the ex-dividend day are used to calculate the change in the stock price between the cum dividend day and the ex-dividend day. This implies that there is no need to adjust for the stock market performance during the ex-dividend day. This is an advantage as the market return on the ex-dividend day may not be a good approximation for the price behavior of the individual stock. As a cause of the previously documented (e.g., Skinner, 1993; Michaely and Vila, 1995) negative correlation between the ex-dividend price ratio and the beta value, and the positive correlation between the former variabel and the dividend yield; parameter $\beta$ is expected to be negative, while $\theta$ and $\gamma$ are expected to be positive.

To study how tax policy regime shifts influence the ex-dividend price ratio, the years when the tax on dividends and capital gains were uniform at a rate of 30 percent (1991 and 1995) are treated as the base period. The period before the implementation of the 1991 tax reform, when long-term capital gains were taxed more favorably than dividends, is characterized by the first dummy variable $\left(T_{1}\right)$. The second dummy variable $\left(T_{2}\right)$ represents the years 1992-1993, when capital gains were taxed at a 5 percent lower rate than dividends. Finally, the third dummy variable $\left(T_{3}\right)$ represents the year 1994 when the tax on dividends was zero; while the capital gains tax rate was 12.5 percent.

The flat tax rate on dividends and capital gains, following the Swedish tax policy regime shift in 1991, provides an opportunity to include direct measures of the differential tax treatment of dividends and capital gains. The tax policy regime shifts following the 1991 tax reform can, thereby, be separated from other period specific developments, e.g., technological changes. This is, however, not possible for the period 1988-1990 because dividends and capital gains during this period were taxed as earned income. The determinants of the ex-dividend price ratio are, therefore, also estimated for the subperiod 1991-1995. The estimating equation is, in this case, given 
by

$$
\frac{P_{c i t}-P_{x i t}}{D_{i t}}=\alpha+\beta b_{i t}+\gamma\left(\frac{D_{i t}}{P_{c i t}}\right)+\eta M_{k}+\varepsilon_{i t}
$$

where $M_{k}=\frac{\left(1-\tau_{d k}\right)}{\left(1-\tau_{g k}\right)}$ is a direct measure of the differential tax treatment of dividends and capital gains for period $k(k=1,2,3$.). During the years when dividends and capital gains were taxed at a uniform rate of 30 percent irrespective of the level of earned income, i.e., 1991 and 1995, it follows that $M_{k}=M_{1}=1$. For the period 1992-93 and, for 1994, the direct measure of the differential tax treatment of dividends and capital gains is given by $M_{2}=\frac{(1-0.3)}{(1-0.25)}=0.933$ and $M_{3}=\frac{(1-0)}{(1-0.125)}=1.143$, respectively. This implies that the effect of relative changes in the taxation of dividends and capital gains can be interpreted from the value of $\eta$. If the price change on the ex-dividend day, as suggested by Elton and Gruber (1970) (see equation (2)), is solely driven by the differential tax treatment of dividends and capital gains; then $\eta=1$ and $\alpha, \beta, \gamma=0$.

\subsection{Arbitrage behavior}

In order to study whether there are any indications of arbitrage behavior, trading volumes are studied using an event time method (see Brown and Warner, 1980, 1985). The daily trading volume for each share is first multiplied by the closing price for each stock. Following Lakonishok and Vermaelen (1986), possible abnormal trading volumes are computed for an eleven-day period beginning five days before the ex-dividend day and ending five days after the ex-day $(-5<t<5)$ using a standardized procedure. The abnormal trading volume for a given share $i$ in a given day $t$ is defined as the difference between the actual trading volume on day $t$ and the estimated normal trading volume. The normal trading volume for each share is estimated as the daily average trading volume for the year preceding the ex-dividend day, excluding the trading days within the event window.

To investigate whether short-term trading is an important feature, i.e., if abnormal high trading volumes are observed around the ex-dividend day, standardized abnormal volumes are first defined as

$$
S A V_{i t}=\frac{A V_{i t}}{\sigma\left(\overline{A V_{i t}}\right)},
$$

where $A V_{i t}$ is the abnormal trading volume on day $t$ for each share, and the denominator gives the standard deviation of the abnormal trading volume 
for the period between the previously considered and the present event windows. To test whether abnormal trading volumes are present around the ex-dividend day, $\mathrm{t}$-values are computed in the following way

$$
\widehat{t}_{t}=\frac{\sum_{i=1}^{N} S A V_{i t} / N}{\sigma(\overline{S A V})},
$$

where $N$ is the number of observations and $\sigma(\overline{S A V})$ is the standard deviation of the mean standardized abnormal trading volume, which is approximated by the square root of the inverse of the number of observations.

The use of regular t-statistics may, however, be questioned because standardized abnormal volumes are skewed. To adjust for skewness, Johnson's (1978) modified t-statistics will be calculated. The adjusted t-value is given by

$$
\widehat{\hat{t}_{t}}=\widehat{t_{t}}+\left(\frac{S}{6 \sqrt{N}}\right)\left(1+2 \widehat{t}^{2}\right)
$$

where $\widehat{t}_{t}$ is the conventional t-statistics given by (7) and $S$ is the sample skewness. Finally, the estimated abnormal values will be compared with the dividend yields to investigate whether abnormal trading volumes, as predicted by the short-term trading hypothesis, are more common for high dividend yield stocks.

\section{Results}

Table 3 shows the results from the estimation of equations (5) and (6). The Elton and Gruber (1970) model suggests (see equation (2)) that $\delta_{1}$ and $\delta_{2}$ should be negative; while $\delta_{3}$ and $\eta$ should be positive. As can been seen from Table 3 , all parameters except $\delta_{1}$ have the expected sign. However, none of these parameters are statistically significant at the conventional $5 \%$ level. This means that the hypothesis that the ex-dividend price ratio is unaffected by the implemented tax policy changes in Sweden during the 1990s cannot be rejected.

\section{Table 3 ABOUT HERE}

For the period following the 1991 tax reform, the dividend yield effect $(\gamma)$ is positive and significant. However, since capital gains and dividends during this period were taxed independently of earned income, the observed positive correlation cannot be due to the tax clientele effect. Moreover, for the pre-1991 tax reform period, the parameter estimate $(\theta)$ does not show 
any significant relationship between the ex-dividend price ratio and dividend yields. Contrary to the results presented in previous empirical studies, the estimation of the parameter $\beta$ is not statistically significantly different from zero. This result can be due to the fact that the use of ex-dividend opening prices (instead of closing prices) decreases the size of the risk component.

Table 4 provides the results for the abnormal volumes and standardized abnormal volumes around the ex-dividend day, subdivided into different tax policy regimes. Abnormal volumes are presented both in SEK (thousands) and as percent of normal volume.

Table 4 ABOUT HERE

For the entire sample period (1988-95), statistically significant volume increases are found in days -2, -1, 0, and 1. Except for the period 1992-93, most abnormal volumes are not significantly different from zero for days 2 through 5. These results are consistent with results from previous studies showing significantly abnormal volumes around the ex-dividend day. For example, Lakonishok and Vermaelen (1986) find significant volume increases for the event days -4 through 2, Michaely and Murgia (1995) and Koski and Scruggs (1998) for days $-2,-1$ and 0.

The analysis of the different tax regimes reveals differences in trading behavior in the period around the ex-dividend day. According to the results, abnormal volumes are most pronounced for the periods when capital gains were taxed differently than dividends. For the period 1992-93 and for 1994 , volumes are as much as 234.5 percent and 274.57 percent, respectively, higher than the normal trading volume on the ex-dividend day. This result is weak evidence in favor of the short-term trading hypothesis, since this theory predicts that greater tax heterogeneity increases the opportunities for short-term traders to make arbitrage profits.

However, despite the differences in the taxes on long-term capital gains and on dividends, abnormal volumes are smallest, both in absolute and percentage terms, during the first period (1988-90). One possible explanation is that the marginal private investor during this period realizes short-term capital gains and is, thereby, characterized by $\tau_{d}=\tau_{g}$. Statistically significant volume increases are, moreover, found for the years 1991 and 1995 when both dividends and capital gains were taxed at a 30 percent flat tax rate. According to the short-term trading hypothesis, no abnormal volumes should be observed during these periods because institutional investors have no tax incentive to engage in dividend capture trading. This result can, however, be due to the fact that the cum-dividend day in Sweden coincides with the annual general meeting of shareholders. Hence, the release of firm specific information and/or the increased publicity may produce volume increases 
unrelated to the dividend pay-out.

To test whether abnormal trading volumes are more pronounced for shares with high dividend yields, the sample is divided into three dividend yield groups where $1=$ low dividend yield group, $2=$ middle dividend yield group, and $3=$ high dividend yield group. These groups consist of stocks with a dividend yield: less than or equal to 1.90 percent, between 1.91 and 2.99 percent, and higher than 3 percent. Abnormal volumes for the different dividend yield groups are presented in Tables 5 and 6 for the cum $(t=-1)$ and the ex-dividend day $(t=0)$, respectively.

\section{Table 5 and 6 ABOUT HERE}

Previous studies have shown a strong positive relationship between abnormal volumes and dividend yields. However, despite the relatively large tax regime changes in Sweden during the 1990s, this result cannot be confirmed by the results presented in Tables 5 and 6 . During the period studied (1988-95), abnormal volumes are observed for all dividend yield groups. There is, moreover, no indication that abnormal volumes are significantly lower for low dividend yield stocks, as previously documented by Lakonishok and Vermaelen (1986).

On the other hand, the results differ between the different tax policy regimes. As previously shown in Table 4, abnormal volumes are smallest before the implementation of the major tax reform in 1991. Furthermore, the results presented in Tables 5 and 6 do not indicate that abnormal volumes are more common for high dividend yield stocks during this period. In accordance with results from previous studies, there are some weak indications that abnormal volumes increased with dividend yields during the periods when capital gains were taxed more favorably than dividends. However, more surprisingly, there is no statistically significant evidence of abnormal volumes in high yield stocks in 1994 when the marginal tax rate on dividends was zero. On the contrary, the results indicate that investors focused their trading on low dividend yield stocks.

\section{Conclusions}

In this study, the effects of the differential taxation of dividends and capital gains on ex-dividend price behavior and trading volumes have been studied using data from Sweden.

The results from the empirical study cannot reject the hypothesis that the ex-dividend price ratio is unaffected by the relatively large tax changes in Sweden during the 1990s. This result provides evidence against the Elton 
and Gruber (1970) model, where the ex-dividend price ratio is solely driven by the differential tax treatment of capital gains and dividends. Moreover, as a result of the flat tax rate of dividends and capital gains, the statistically significant relation between the ex-dividend price ratio and the dividend yields, observed after 1991, cannot be a consequence of tax induced clienteles.

For the entire sample period, significantly positive abnormal volumes are observed for days $-2,-1,0$, and 1 . However, since the cum-dividend day in Sweden coincides with the annual general meeting of shareholders, new information can explain the increased trading volumes in the period around the ex-dividend day. The strong positive relation between abnormal volumes and dividend yields found elsewhere is, moreover, not observed in the data. It is especially interesting to note that no significant abnormal volume increases can be observed in high yield stocks during 1994 when dividends were tax exempt. Hence, during this period, it does not seem as if the institutional traders follow the short-term trading strategy to sell shares on the cum-dividend day and buy them on the ex-dividend day in order to exploit the arbitrage opportunities offered by the Swedish tax system. Further work should, therefore, consider whether dividend capture trading, where stock index futures are used to hedge against the market risk (see Dubofsky and Kannan, 1993), has been a viable short-term trading strategy for institutional investors.

Finally, note that the decline in the stock price between the cum and the ex-dividend day is closer to the dividend per share when dividends are relatively large; despite no indications of tax induced clienteles or more pronounced trading volumes for shares with high dividend yields. This may indicate that investors prefer low dividend yield stocks because capital gains, in contrast to dividends, are taxed on realization rather than accrual. Another explanation is that the tick effect is more important when dividends are relatively small (see Bali and Hite, 1998), thereby, creating an ex-dividend price ratio closer to one for high dividend yield stocks.

\section{References}

Agell J., Englund P., and Södersten J. (1998), Incentives and Redistribution in the Welfare State: The Swedish Tax Reform, MacMillian Press, Oxford.

Athanassakos G. (1996), "Tax Induced Trading Volume Around Ex-dividend Days Under Different Tax Regimes: The Canadian Experience 1970- 
1984", Journal of Business Finance and Accounting, 23, 557-584.

Athanassakos G., and Fowler D. (1993), "New Evidence on the Behavior of Canadian Stock Prices in the Days Surrounding the Ex-dividend Day", Quarterly Journal of Business and Economics, 32, 26-50.

Bali R., and Hite G.L. (1998), "Ex Dividend Day Stock Price Behavior: Discreteness or Tax-Induced Clienteles?", Journal of Financial Economics, 47, 127-159.

Barclay M.J. (1987), "Dividends, Taxes and Common Stock Prices", Journal of Financial Economics, 19, 31-44.

Booth L., and Johnston D. (1984), "The Ex-Dividend Behavior of Canadian Stock Prices: Tax Changes and Clientele Effects", Journal of Finance, 39, 457-476.

Boyd J.H., and Jagannathan R. (1994), "Ex-Dividend Price Behavior of Common Stocks", Review of Financial studies, 7, 711-741.

Brown S.J., and Warner J.B. (1980), "Measuring Security Price Performance", Journal of Financial Economics, 8, 205-258.

Brown S.J., and Warner J.B. (1985), "Using Daily Stock Returns: The Case of Event Studies", Journal of Financial Economics, 14, 3-31.

Campbell J., and Beranek W. (1953), "Stock Price Behavior on Ex-Dividend Dates", Journal of Finance, 10, 425-429.

Dubofsky D.A., and Kannan S. (1993), "Hedged Dividend Capture Trading and Ex-day Returns: An Empirical Update", Journal of Business, Finance and Accounting, 20, 725-734.

Durand D., and May A. (1960), "The Ex-Dividend Behavior of American Telephone and Telegraph Stocks", Journal of Finance, 15, 19-31.

Elton E.J., and Gruber M.J. (1970), "Marginal Stockholder Tax Rates and the Clientele Effect", Review of Economics and Statistics, 52, 68-74.

Heath D.C., and Jarrow R.A. (1988), "Ex-Dividend Stock Price Behavior and Arbitrage Opportunities", Journal of Business, 61, 95-108.

Johnson N. (1978), "Modified t-tests and Confidence Intervals for Asymmetric Population", Journal of the American Statistical Association, 73, 536-544.

Kalay A. (1982), "The Ex-Dividend Day Behavior of Stock Prices: A ReExamination of the Clientele Effect, Journal of Finance, 37, 1059-1070. 
Kalay A. (1984), "The Ex-Dividend Day Behavior of Stock Prices; A ReEximination of the Clientele Effect: A Reply", Journal of Finance, 39, $557-561$.

Karpoff J.M., and Walkling R.A. (1988), "Short-term Trading Around ExDividend Days", Journal of Financial Economics, 21, 291-298.

Koski J.L., and Scruggs J.T. (1998), "Who Trades Around the Ex-dividend Day? Evidence from NYSE Audit File Data", Financial Management, $27,58-72$.

Lakonishok J., and Vermaelen T. (1986), "Tax Induced Trading Around Ex-Dividend Days", Journal of Financial Economics, 16, 287-319.

Michaely R. (1991), "Ex-Dividend Stock Price Behavior : The Case of the 1986 Tax Reform Act", Journal of Finance, 46, 845-860.

Michaely R., and Murgia M. (1995), "The Effect of Tax Heterogenity on Prices and Volume around the Ex-dividend Day: Evidence from the Milan Stock Exchange", The Review of Financial Studies, 8, 369-399.

Michaely R., and Vila J-L. (1995), "Investors' Heterogenity, Prices and Volume around the Ex-Dividend Day", Journal of Financial and Quantitative Analysis, 30, 171-198.

Miller M.H., and Modigliani F. (1961), "Dividend Policy, Growth and the Valuation of Shares", Journal of Business, 34, 411-33.

Miller M.H., and Scholes M. (1982), "Dividends and Taxes: Some Empirical Evidence", Journal of Political Economy, 90, 1118-41.

Poterba J.M., and Summers L.H. (1984), "New Evidence That Taxes Affect the Valuation of Dividends", Journal of Finance, 39, 1397-1415.

de Ridder A., and Södersten T. (1995), "Ex-Dividend Behavior and the Swedish Tax Reform", Tax Reform Evaluation Report No 10, Uppsala University.

Robin A.J. (1991), "The Impact of the 1986 Tax Reform Act on Ex-dividend Day Returns", Financial Management, 20, 60-70.

Skinner D.L. (1993), "Twenty-five Years of Tax Law Changes and Investor Response", Journal of Financial Research, 16, 61-70.

Wu C., and Hsu J. (1996), "The Impact of the 1986 Tax Reform on Exdividend Day Volume and Price Behavior", National Tax Journal, 49, 177-192. 
Table 1: Tax Regimes in Sweden 1988-95

\begin{tabular}{lcc}
\hline \hline Year & $\begin{array}{c}\text { Dividend tax } \\
\text { rate }\end{array}$ & $\begin{array}{c}\text { Capital gain } \\
\text { tax rate }\end{array}$ \\
\hline $1988-90$ & $54 \%$ & $54 \%^{a}$ \\
$1988-90$ & $54 \%$ & $21.6 \%^{b}$ \\
1991 & $30 \%$ & $30 \%$ \\
$1992-93$ & $30 \%$ & $25 \%$ \\
1994 & $0 \%$ & $12.5 \%$ \\
1995 & $30 \%$ & $30 \%$ \\
\hline
\end{tabular}

${ }^{a}$ Given that the individual faces an income tax rate of 54 percent.

${ }^{b}$ During 1988-90, long term capital gains (>2 years) were taxable at 40 percent. 
Table 2: Descriptive statistics for cash dividends in Sweden 1988-95.

Standard errors are reported in parantheses

\begin{tabular}{|c|c|c|c|c|c|}
\hline Period & $\begin{array}{c}\text { Relative taxation } \\
\text { of dividends and } \\
\text { capital gains }{ }^{b}\end{array}$ & $\begin{array}{c}\text { Mean } \\
\text { ex-dividend } \\
\text { price ratio }^{c} \\
\end{array}$ & $\begin{array}{c}\text { Mean } \\
\text { dividend } \\
\text { yield } \\
\end{array}$ & $\begin{array}{c}\text { Mean } \\
\text { trading } \\
\text { volume }^{d} \\
\end{array}$ & $\begin{array}{c}\text { Number } \\
\text { of } \\
\text { observations } \\
\end{array}$ \\
\hline 1988-90 & $-{ }_{-a}$ & $\begin{array}{c}0.51 \\
(2.24)\end{array}$ & $\begin{array}{c}2.08 \\
(1.14)\end{array}$ & $\begin{array}{c}4302593 \\
(7574592)\end{array}$ & 114 \\
\hline 1992-93 & 0.933 & $\begin{array}{c}0.22 \\
(2.62)\end{array}$ & $\begin{array}{c}3.35 \\
(1.77)\end{array}$ & $\begin{array}{c}8930028 \\
(21998814)\end{array}$ & 88 \\
\hline 1994 & 1.143 & $\begin{array}{c}0.55 \\
(2.05)\end{array}$ & $\begin{array}{c}2.13 \\
(1.06)\end{array}$ & $\begin{array}{c}47875030 \\
(161262441)\end{array}$ & 53 \\
\hline 1991, 1995 & 1 & $\begin{array}{c}0.61 \\
(1.35)\end{array}$ & $\begin{array}{c}3.18 \\
(1.61)\end{array}$ & $\begin{array}{c}31108064 \\
(88774979)\end{array}$ & 116 \\
\hline 1988-1995 & $-{ }^{a}$ & $\begin{array}{c}0.48 \\
(2.08) \\
\end{array}$ & $\begin{array}{c}2.73 \\
(1.56) \\
\end{array}$ & $\begin{array}{c}20006065 \\
(80564911) \\
\end{array}$ & 371 \\
\hline
\end{tabular}

${ }^{a}$ The relative taxation of dividends and capital gains cannot be computed for this period because the value depends on how much income the individual earns.

${ }^{b}$ Given by: $\left(\left(1-\tau_{d}\right) /\left(1-\tau_{g}\right)\right)$; where $\tau_{d}=$ marginal tax rate on dividends, and $\tau_{g}=$ marginal tax rate on capital gains.

${ }^{c}$ Given by: $\left(\left(\mathrm{P}_{\mathrm{C}}-\mathrm{P}_{\mathrm{X}}\right) / \mathrm{D}\right)$; where $\mathrm{P}_{\mathrm{C}}=$ closing price on the cum dividend day in Swedish crowns (SEK), $\mathrm{P}_{\mathrm{X}}=$ opening price on the ex-dividend day in Swedish crowns (SEK), and $\mathrm{D}=$ dividend per share in Swedish crowns (SEK).

${ }^{d}$ Measured as the daily trading volume on the cum-dividend day multiplied by the closing price in Swedish crowns (SEK). 
Table 3: Estimates of the determinants of the ex-dividend price ratio in Sweden 1988-1995

\begin{tabular}{lcc|cc}
\hline \hline & \multicolumn{2}{c}{ Eq. $(5)^{a}$} & \multicolumn{2}{c}{ Eq. $(6)^{b}$} \\
Variable $($ Parameter $)$ & Estimate & t-value & Estimate & t-value \\
\hline Constant $(\alpha)$ & 0.06 & 0.17 & -2.64 & -1.46 \\
Beta $(\beta)$ & -0.002 & -0.24 & -0.003 & -0.26 \\
Dividend yield 88-90 $(\theta)$ & 0.16 & 0.94 & - & - \\
Dividend yield 91-95 $(\gamma)$ & 0.18 & 2.13 & 0.18 & 2.30 \\
Tax regime 1988-90 $\left(\delta_{1}\right)$ & 0.12 & 0.24 & - & - \\
Tax regime 1992-93 $\left(\delta_{2}\right)$ & -0.43 & -1.46 & - & - \\
Tax regime 1994 $\left(\delta_{3}\right)$ & 0.12 & 0.33 & - & - \\
Relative taxation $(\eta)$ & - & - & 2.54 & 1.48 \\
\hline
\end{tabular}

${ }^{a}$ Eq.(5) is based on the full sample period 1988-95.

${ }^{b}$ Eq.(6) is based on the subsample period 1991-95. 


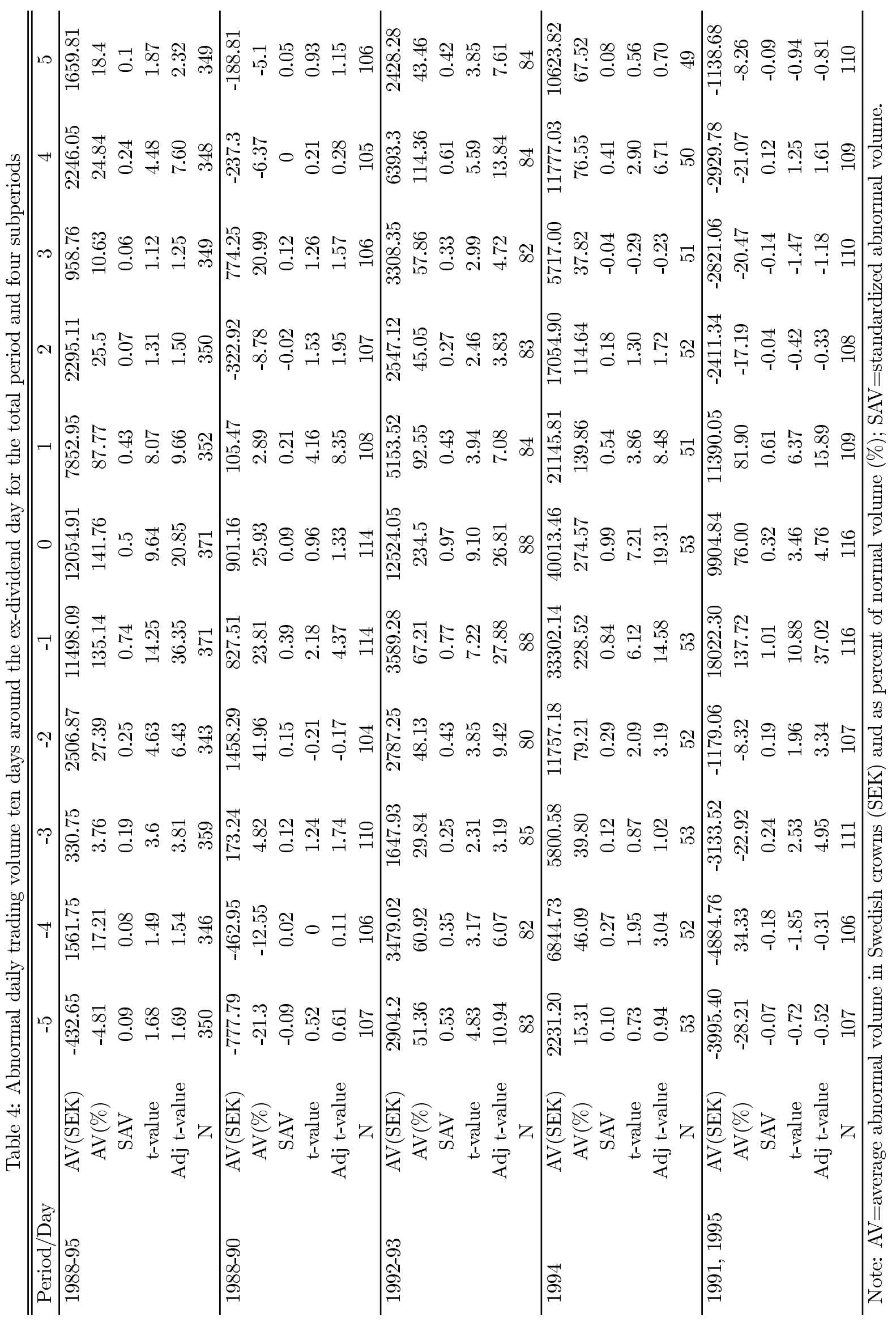


Table 5: Abnormal trading volume at the cum dividend day $(\mathrm{t}=-1)$ as a function of dividend yield

\begin{tabular}{lccccccc}
\hline \hline Period & Yield group & AV(SEK) & AV(\%) & SAV & t-value & Adj t-value & N \\
\hline \multirow{2}{*}{$1988-95$} & 1 & 17807.6 & 167.36 & 0.5 & 5.48 & 9.09 & 120 \\
& 2 & 10834.08 & 129.85 & 1.01 & 11.29 & 28.38 & 125 \\
\multirow{3}{*}{$1988-90$} & 3 & 6147.81 & 92.58 & 0.69 & 7.75 & 17.19 & 126 \\
& 1 & 719.62 & 32.41 & -0.01 & -0.07 & -0.002 & 55 \\
& 2 & 1243.72 & 39.52 & 1.15 & 7.18 & 19.15 & 39 \\
$1992-93$ & 3 & 312.57 & 4.13 & 0 & 0 & 0.05 & 20 \\
& 1 & 5350.76 & 70.65 & 0.42 & 1.68 & 2.12 & 16 \\
& 2 & 5060.69 & 74.74 & 0.48 & 2.54 & 3.51 & 28 \\
1994 & 3 & 2012.39 & 55.61 & 1.07 & 7.10 & 17.77 & 44 \\
& 1 & 59211.55 & 272.88 & 1.42 & 7.38 & 13.20 & 27 \\
& 2 & 10024.73 & 114.67 & 0.46 & 1.90 & 2.23 & 17 \\
1991,1995 & 3 & -457.63 & -10.87 & -0.17 & -0.51 & -0.43 & 9 \\
& 1 & 18773.1 & 92.26 & 0.71 & 3.33 & 6.31 & 22 \\
& 2 & 24235.02 & 170.67 & 1.47 & 9.41 & 22.95 & 41 \\
& 3 & 12904.59 & 140.12 & 0.77 & 5.61 & 8.36 & 53 \\
\hline
\end{tabular}

Note: Yield group: $1=$ lowest yield, $3=$ highest yield; $\mathrm{AV}(\mathrm{SEK})=$ average abnormal volume in Swedish crowns; $\mathrm{AV}(\%)=$ average abnormal volume as percent of normal volume; $\mathrm{SAV}=$ standardized abnormal volume; $\mathrm{N}=$ number of observations. 
Table 6: Abnormal trading volume at the ex-dividend day $(\mathrm{t}=0)$ as a function of dividend yield.

\begin{tabular}{lccccccc}
\hline \hline Periods & Yield group & AV(SEK) & AV(\%) & SAV & t-value & Adj t-value & N \\
\hline \multirow{2}{*}{$1988-95$} & 1 & 25077.29 & 235.69 & 0.73 & 8.0 & 13.79 & 120 \\
& 2 & 5900.23 & 70.72 & 0.31 & 3.47 & 3.77 & 125 \\
\multirow{3}{*}{$1988-90$} & 3 & 5882.94 & 88.59 & 0.48 & 5.39 & 9.14 & 126 \\
& 1 & 1381.9 & 62.23 & 0.21 & 1.56 & 2.14 & 55 \\
& 2 & 79.5 & 2.53 & -0.06 & -0.37 & 0.46 & 39 \\
$1992-93$ & 3 & 1181.38 & 15.60 & 0.07 & 0.31 & 0.33 & 20 \\
& 1 & 38906.54 & 513.71 & 1.57 & 6.28 & 13.70 & 16 \\
& 2 & 9177.58 & 135.54 & 0.57 & 3.02 & 3.73 & 28 \\
1994 & 3 & 5060.0 & 139.83 & 1.01 & 6.70 & 13.63 & 44 \\
& 1 & 70180.58 & 323.44 & 1.52 & 7.90 & 15.85 & 27 \\
& 2 & 13011.58 & 148.92 & 0.68 & 2.80 & 3.81 & 17 \\
1991,1995 & 3 & 502.43 & 11.93 & -0.02 & -0.06 & 0.05 & 9 \\
& 1 & 18904.07 & 92.91 & 0.42 & 1.97 & 2.32 & 22 \\
& 2 & 6247.33 & 44.0 & 0.33 & 2.11 & 2.04 & 41 \\
& 3 & 9253.97 & 100.48 & 0.28 & 2.04 & 2.89 & 53 \\
\hline
\end{tabular}

Note: Yield group: $1=$ lowest yield, $3=$ highest yield; $\mathrm{AV}(\mathrm{SEK})=$ average abnormal volume in Swedish crowns; $\mathrm{AV}(\%)=$ average abnormal volume as percent of normal volume; $\mathrm{SAV}=$ standardized abnormal volume; $\mathrm{N}=$ number of observations. 